University of Nebraska - Lincoln

DigitalCommons@University of Nebraska - Lincoln

March 1999

\title{
Nonspecific interactions alter lipopolysaccharide patterns and protein mobility on sodium dodecyl sulfate polyacrylamide gels
}

\author{
Aidong Yuan \\ University of Nebraska-Lincoln \\ R L. Pardy \\ rpardy2@unl.edu \\ Catherine P. Chia \\ University of Nebraska-Lincoln, cchia1@unl.edu
}

Follow this and additional works at: https://digitalcommons.unl.edu/bioscimicro

Part of the Microbiology Commons

Yuan, Aidong; Pardy, R L.; and Chia, Catherine P., "Nonspecific interactions alter lipopolysaccharide patterns and protein mobility on sodium dodecyl sulfate polyacrylamide gels" (1999). Papers in Microbiology. 73.

https://digitalcommons.unl.edu/bioscimicro/73

This Article is brought to you for free and open access by the Papers in the Biological Sciences at DigitalCommons@University of Nebraska - Lincoln. It has been accepted for inclusion in Papers in Microbiology by an authorized administrator of DigitalCommons@University of Nebraska - Lincoln. 


\title{
Nonspecific interactions alter lipopolysaccharide patterns and protein mobility on sodium dodecyl sulfate polyacrylamide gels
}

\author{
Aidong Yuan, Roosevelt L. Pardy, and Catherine P. Chia \\ School of Biological Sciences, University of Nebraska-Lincoln, Lincoln, NE, USA \\ Correspondence: Dr. Aidong Yuan, School of Biological Sciences, 348 Manter Hall, University of Nebraska-Lincoln, \\ Lincoln, NE 68588-0118, USA. Email: dyuan@unserve.unl.edu Fax: 402-472-2083
}

\begin{abstract}
In testing whether bacterial lipopolysaccharide (LPS) was a natural substrate for an esterase from the soil amebae Dictyostelium discoideum, we observed altered banding patterns of the LPS and changed protein mobility on sodium dodecyl sulfate (SDS) polyacrylamide gels after incubation of LPS with the enzyme. The initial interpretation of these results was that the enzyme had removed ester-linked acyl chains from the LPS, leading to a change in its migration on gels. However, esterase inactivated by treatment with either dithiothreitol (DTT), heat, or SDS generated the same mobility shifts. Bovine serum albumin (BSA) also induced the same change in the electrophoretic pattern. We conclude that the altered LPS patterns and protein mobility on SDS gels were caused by nonspecific interactions between LPS and protein.
\end{abstract}

Keywords: Lipopolysaccharide, Lipopolysaccharide-protein interaction, Ladder-like pattern, Gel electrophoresis

Abbreviations: LPS, lipopolysaccharide; SPB, sample preparation buffer

\section{Introduction}

Bacterial lipopolysaccharides (LPS), also known as endotoxin, are the major component of the outer membrane of Gram-negative bacteria on which amebae of the slime mold Dictoostelium discoideum feed. $D$. discoideum cells contain an esterase activity which specifically cleaves long-chain fatty acids from the lipid A component of bacterial lipopolysaccharides [1]. In studies of cytokeletally associated proteins, we found a $70 \mathrm{kDa}$ glycoprotein (gp70) enriched in the detergent-insoluble fraction of axenically grown cells [2]. $\mathrm{N}$-terminal amino acid sequence of gp70 identified it to be "crystal protein" [3] and biochemical assays demonstrated its esterase activity [2]. Changes in the electrophoretic pattern of bacterial LPS in SDS polyacrylamide gels were interpreted as evidence of LPS degradation by gut juice of the snail Helix pomatia [4]. We used this method to test whether bacterial LPS was a natural substrate of gp70. After incubating LPS and gp70 together, we observed altered LPS banding patterns as well as changes in the mobility of gp70 on SDS gels. The initial interpretation of these results was that cleavage of ester-linked acyl chains from LPS by gp70 led to a change in the migration of the LPS. However, the same altered LPS ladder pattern and shift in gp70 mobility were generated when inactivated esterase or BSA was used. Therefore, careful interpretation of modified LPS profiles on SDS gels is warranted when LPS-protein interactions are postulated.

\section{Materials and methods}

\subsection{Preparation of LPS and gp70}

LPS was purified from late log phase cultures of Serratia marcescens (a gift of Dr. K. Nickerson, University of Nebraska-Lincoln) following proteinase $\mathrm{K}$ digestion [5]. Gp70 was purified from the cytoskeletal fraction of the transformed $D$. discoideum cell line AT-K2 that overexpresses crystal protein [2]. Briefly, cytoskeletons were prepared and solubilized from AT-K2 cells grown to $1 \times 10^{7}$ cells $/ \mathrm{mL}$ at $20^{\circ} \mathrm{C}$ in $\mathrm{HL} 5$ media [6] containing $10 \mathrm{mg} / \mathrm{mL}$ G418 [2]. Gp70 was isolated from the cytoskeletal fraction either by immunoaffinity chromatography [7] using protein Gpurified monoclonal antibody $130-80-2$ specific for gp70 [3], or Concanavalin A affinity chromatography [2], or by centrifuging the solubilized cytoskeletons at $10,000 \times g$ for $1 \mathrm{~h}$ to pellet detergent-insoluble actin filaments and associated proteins. The concentration of purified gp70 was determined by comparison to known amounts of BSA run concurrently on Coomassie blue-stained SDS gels.

\subsection{Assay for esterase activity of gp70}

The esterase activity of gp70 was determined spectrophotometrically using the substrate a-naphthyl acetate in a general esterase assay as described previously [2]. Alternately, one milligram of LPS from Serratia marcescens was dissolved in $1 \mathrm{~mL}$ of $50 \mathrm{mM}$ MOPS buffer, $\mathrm{pH} 7.5$, and sonicated at $4^{\circ} \mathrm{C}$ for $30 \mathrm{~min}$ in a FS3 ultrasonic water bath (Fisher 
Scientific, Hampton, NH) which made the LPS solution appear opalescent. Twenty microliters (20 $\mu \mathrm{g})$ of the LPS solution were incubated with $5 \mu \mathrm{L}$ $(0.2 \mu \mathrm{g} / \mu \mathrm{L})$ of gp70 and $15 \mu \mathrm{L}$ of deionized water at $30^{\circ} \mathrm{C}$ for $30 \mathrm{~min}$. In some experiments, BSA instead of gp70, or gp70 inactivated (verified using the general esterase assay) by treatment with 250 $\mathrm{mm}$ DTT $\left(4^{\circ} \mathrm{C}\right.$ for $\left.30 \mathrm{~min}\right), 4 \% \mathrm{SDS}\left(4^{\circ} \mathrm{C}\right.$ for $\left.30 \mathrm{~min}\right)$ or heat $\left(10 \mathrm{~min}\right.$ at $\left.100^{\circ} \mathrm{C}\right)$ was mixed with the LPS.

\subsection{Gel electrophoresis}

The incubated LPS-protein mixture $(40 \mu \mathrm{L})$ was heat-denatured $\left(100^{\circ} \mathrm{C}\right.$ for $\left.5 \mathrm{~min}\right)$ with $10 \mu \mathrm{L}$ of $5 \times$ SDS Laemmli sample preparation buffer (SPB) [8]. Ten microliters were loaded per lane of $7.5 \%$ polyacrylamide SDS (mini)-gels [8] containing $4 \mathrm{~m}$ urea [9]. Prestained protein standards of high molecular mass (Gibco BRL Life Technologies, Rockville, MD) were: myosin heavy chain (200 kDa), phosphorylase (97 kDa), BSA (68 kDa), ovalbumin (43 kDa), and carbonic anhydrase (29 kDa).

\subsection{Silver staining}

Gels were stained with silver according to Tsai and Frasch [9] with minor modifications. Briefly, gels were fixed for $30 \mathrm{~min}$ in $40 \%$ ethanol-5\% acetic acid, and then soaked in oxidant ( $0.7 \%$ periodic acid in $40 \%$ ethanol-5\% acetic acid) for 5 min. After three 5 min washes in water, gels were incubated for $10 \mathrm{~min}$ in a freshly prepared ammoniacal silver nitrate solution $(12 \mathrm{~mL}$ of $0.1 \mathrm{~N} \mathrm{NaOH}, 0.8 \mathrm{~mL}$ of $\mathrm{NH}_{4} \mathrm{OH}(28.8 \%), 2 \mathrm{~mL}$ of $20 \% \mathrm{AgNO}_{3}$ and $46 \mathrm{~mL}$ deionized distilled water). After three water washes, gels were developed in freshly prepared $3 \% \mathrm{Na}_{2} \mathrm{CO}_{3}$ containing $0.0185 \%$ formaldehyde. The development was stopped with $50 \mathrm{~mm}$ EDTA, pH 4.6, when the stain reached the desired intensity.

\subsection{Immunoblotting}

Proteins were transferred from gels onto polyvinylidenefluoride membranes (Millipore, Bedford, MA) by semidry electroblotting using Towbin buffer [10]. Blots were shaken for $15 \mathrm{~min}$ in $5 \%$ nonfat

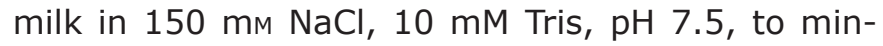
imize nonspecific binding and washed three times ( 5 min each) in Tween buffer (0.1\% Tween-20, 150 $\mathrm{mm} \mathrm{NaCl}, 10 \mathrm{~mm}$ Tris, $\mathrm{pH} 8.0$ ). They were incubated for $1 \mathrm{~h}$ in undiluted hybridoma cell culture supernatant containing a mouse monoclonal antibody, 13080-2, specific for gp70 [2, 3]. Blots were washed again in the Tween buffer and incubated for $1 \mathrm{~h}$ in Tween buffer containing a 1:12,500 dilution of alkaline phosphatase-goat anti-mouse IgG (Sigma, St. Louis, MO). Blots were washed again in the Tween buffer before color development with the substrates 5-bromo-4-chloro-3-indolyl phosphate and nitroblue tetrazolium [7].

\section{Results and discussion}

LPS from Serratia marcescens had a ladder-like pattern on SDS gels (containing $4 \mathrm{~m}$ urea) of eleven bands (Fig. 1, lane 1), consistent with a previously published pattern [11]. The LPS molecules migrated in the range of 35-55 $\mathrm{kDa}$. The protein markers were not appropriate standards for estimating the mass of LPS molecules and were used only as references for monitoring the relative mobilities of the LPS. After incubation with purified gp70, whose activity was verified using a general esterase assay, the ladder-like pattern of Serratia marcescens LPS partly disappeared with only two bands of 45-48 kDa remaining (indicated with + ; lanes 2 and 3). An intensely staining band at roughly $180 \mathrm{kDa}$ was also observed (indicated with $*$ ). The initial interpretation of the pattern alteration was that the enzyme had removed ester-linked acyl chains from the LPS, leading to a change in its migration on gels.

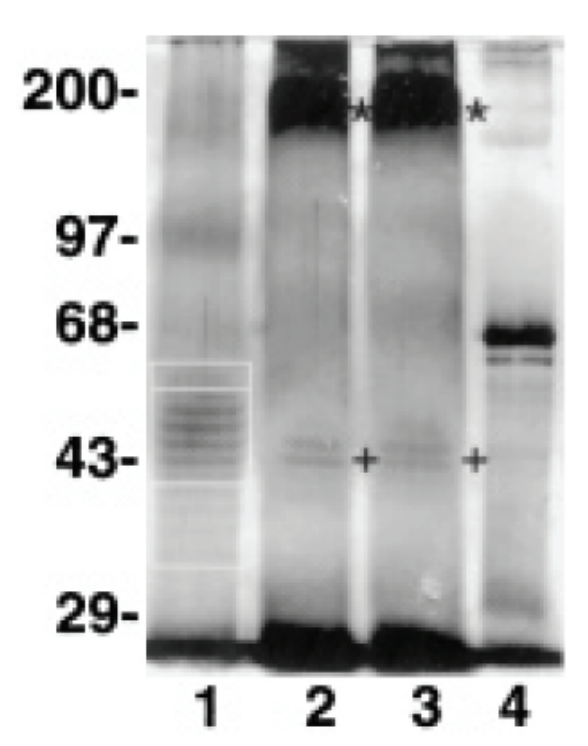

Figure 1. Disappearance of Serratia marcescens LPS bands after incubation with purified $D$. discoideum gp70 on an SDS gel containing $4 \mathrm{~m}$ urea. (See Section 2.2 for assay conditions.) Lane (1) LPS (4 $\mu \mathrm{g})$, (2) LPS incubated with active gp70, (3) LPS incubated with DTT-inactivated gp70, and (4) purified gp70 (0.2 $\mu \mathrm{g})$. In (1) the upper two white boxes outline seven more strongly staining species between 43 and $55 \mathrm{kDa}$ and the lower box outlines four fainter species in the range of 35-42 $\mathrm{kDa}$. In (2) and (3) the symbol (+) indicates two LPS species at approximately $45-48 \mathrm{kDa}$ remaining after incubation, and the symbol (*) indicates apparent LPSprotein associations. The $65 \mathrm{kDa}$ species below gp70 was a breakdown product that occurred upon storage. Sizes (in kDa) of prestained protein molecular markers are indicated to the left of (1). 
Changes in the electrophoretic pattern of LPS bands in SDS gels have been interpreted as evidence of LPS degradation by the gut juice of the snail $\mathrm{He}$ lix pomatia [4]. However, LPS, incubated with gp70 completely inactivated by treatment with DTT, as judged by the esterase assay, generated the same altered ladder pattern (Fig. 1, lane 3) seen with active gp70 (Fig. 1, lane 2). Additional experiments with gp70 denatured with SDS or by boiling also generated the same altered ladder pattern (data not shown). Even mixing LPS in the wells of SDS gels with increasing amounts of the gp70 boiled in SPB for $5 \mathrm{~min}$ also caused the change in the LPS profile (Fig. 2A). To test whether nonspecific protein interactions were responsible for the changes LPS pattern, LPS was incubated under the same conditions with BSA in place of gp70.

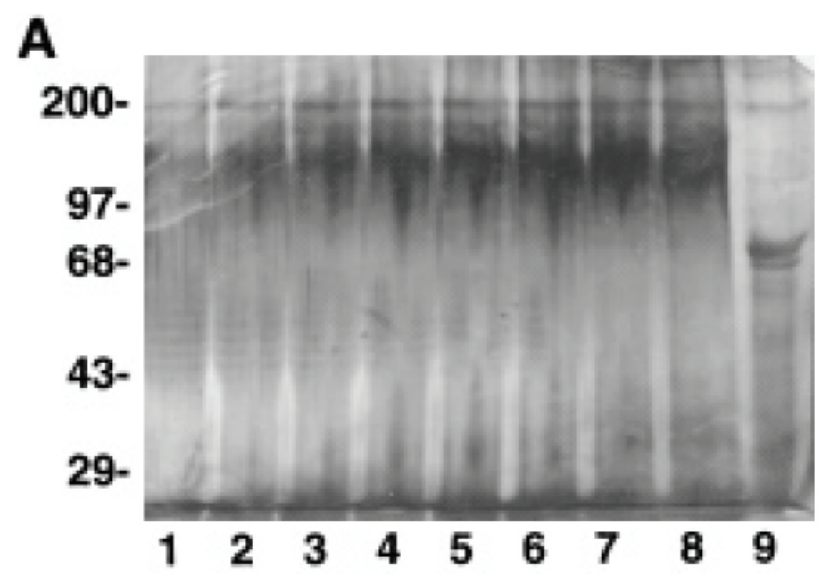

B

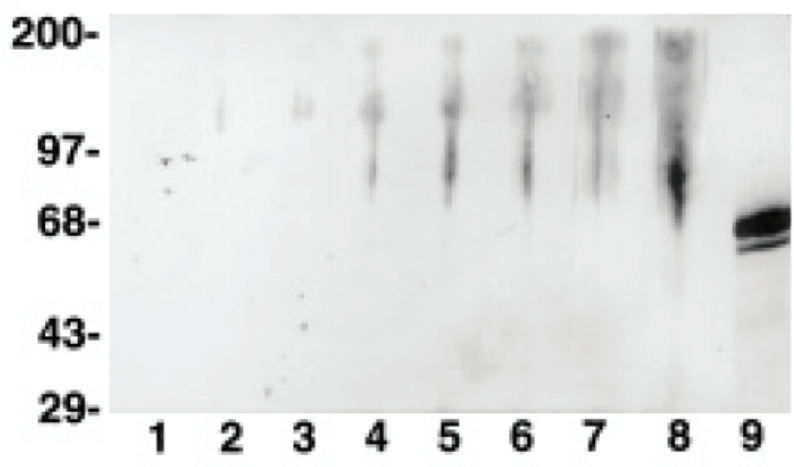

Figure 2. Gradual disappearance of the LPS ladder patterns by (A) increasing amounts of heat-inactivated gp70, and (B) retarded migration and smearing of gp70. (A) Silver-stained SDS gel that contained $4 \mathrm{~m}$ urea; (B) immunoblot of duplicate gel shown in (A) stained with monoclonal antibody 130-80-2 against $D$. discoideum gp70. LPS ( $4 \mu \mathrm{g}$ per lane, in $1 \times \mathrm{SPB})$ was loaded first into lanes $1-8$ and then the following amounts of heat-inactivated gp70 in $1 \times$ SPB were loaded on top of the LPS: lane (1) $0 \mu \mathrm{g}$, (2) $0.02 \mu \mathrm{g}$, (3) $0.04 \mu \mathrm{g}$, (4) $0.06 \mu \mathrm{g}$, (5) 0.08 $\mu \mathrm{g}$, (6) $0.1 \mu \mathrm{g}$, (7) $0.12 \mu \mathrm{g}$, (8) $0.2 \mu \mathrm{g}$, and (9) $0.1 \mu \mathrm{g}$. LPS was omitted from (9). Sizes (in kDa) of prestained protein molecular markers are indicated to the left of (1). The current was turned on immediately after loading the gel.
BSA induced the same change in the electrophoretic pattern of LPS on the gel (Fig. 3). Because the modified LPS pattern was observed whether gp70 was active or denatured, and with BSA, we conclude that the loss of most of the ladder was not the result of enzymatic hydrolysis of LPS subcomponents but rather an artifact of LPS-protein interactions unrelated to the esterase activity of gp70.

The LPS-gp70 interaction caused not only the alteration of the ladder pattern of LPS but also a change in the mobility of the esterase on the gels (Fig. 2B). As shown by immunoblotting, gp70 alone migrated at $67 \mathrm{kDa}$ on the blot (Fig. 2B, lane 9). Once mixed with LPS, gp70 moved as a much larger species (137 kDa; Fig. 2B, lanes 2 and 3), probably as a result of an association with LPS. With increasing amounts of gp70 mixed with LPS, the size of the LPS-gp70 complexes ranged from 67 to $200 \mathrm{kDa}$, based on the smeary signals on both the silver-stained gel and the blot (Fig. 2A and $2 \mathrm{~B}$, lanes 4-8).

Previous studies have shown that bacterial LPS can bind to or associate with many proteins including serum LPSbinding protein LBP [12], CD14 [13], the macrophage scavenger receptor, the beta2 integrins [14], hemoglobin [15], moth hemolin (an insect member of the Ig-superfamily) [16], OmpA of Escherichia coli [17], the S2 subunit of pertussis toxin [18], the $39 \mathrm{kDa}$ membrane protein of Haemophilus influenzae type b [19], and several plasma proteins of rainbow trout [20]. More pertinent to the present study, however, were LPS-protein

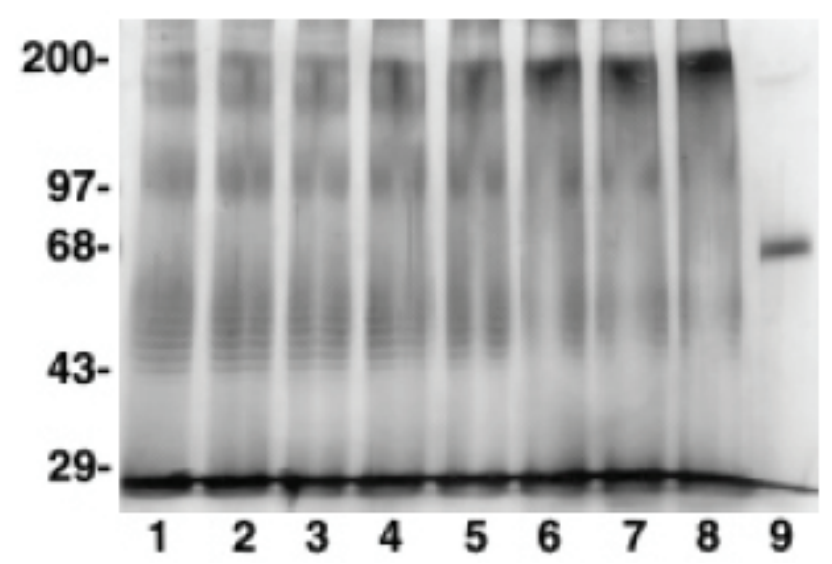

Figure 3. Gradual disappearance of the LPS ladder pattern by increasing amounts of BSA. LPS (4 mg) was loaded in lanes (1)-(8) of an SDS gel containing $4 \mathrm{~m}$ urea, and then the following amounts of BSA in $1 \times$ SPB were loaded on top of LPS. (1) $0 \mu \mathrm{g}$, (2) $0.02 \mu \mathrm{g}$, (3) $0.04 \mu \mathrm{g}$, (4) $0.06 \mu \mathrm{g}$, (5) $0.08 \mu \mathrm{g}$, (6) 0.1 $\mu \mathrm{g},(7) 0.12 \mu \mathrm{g}$, (8) $0.2 \mu \mathrm{g}$, and (9) $0.1 \mu \mathrm{g}$. LPS was omitted from (9). Sizes (in $\mathrm{kDa}$ ) of prestained protein molecular markers are indicated to the left of (1). The current was turned on immediately after loading the gel. 
interactions resistant to dissociation under harsh conditions (i.e., SDS, urea, and high temperature). Similar observations were made with gp70 and Klebsiella-LPS mixtures (data not shown). LPS migration patterns from Neisseria gonorrhoeae [21] and Salmonelle chemotypes [5] are more compact in whole cell lysates compared to their profiles in proteinase K-digested lysates or purified LPS, implicating LPS-protein interactions in producing the altered patterns. The reduced LPS profile in wholecell lysates was demonstrated to be due to the stable association between LPS and many membrane proteins [21].

The conclusions by Saddler et al. [4], who interpreted changes in LPS patterns on SDS-PAGE to be evidence of snail gut juice degradation of LPS, are not invalidated by our findings. In their study, however, no chemical evidence was presented for the degradation of LPS. An alternative explanation for the observed altered gel patterns would be an association of LPS molecules with (protein) components in the gut juice. This interpretation is plausible and consistent with our observations supporting the idea that nonspecific LPS-protein interactions modified the mobility of both LPS and protein on SDS gels.

\section{Concluding remarks}

The conclusion of this study is that nonspecific LPS-protein interactions can alter LPS ladder patterns and protein mobility on SDS gels. The observed noncatalytic LPS-protein associations may lead to the misinterpretation of experimental results if the interactions are not taken into account when analyzing LPS profiles on gels, purifying bacterial antigens as vaccines and studying enzyme effects on LPS.

Were are grateful to Dr. G. Gerisch (Max-Planck Institut für Biochemie, Germany) for providing the hybridoma producing a mouse monoclonal antibody, 130-80-2, specific for gp70 (crystal protein). We also thank Dr. A. Zera (School of Biological Sciences, University of Nebraska- Lincoln) for assistance with protocols to assay esterase activity. These studies were supported by funds from the University of $\mathrm{Ne}-$ braska Research Council (College of Arts and Sciences) and NSF Grant MCB-95133628 to C.P.C.

\section{References}

[1] Malchow, D., Luderitz, O., Kickhofen, B., Westphal, O., Gerisch, G., Eur. J. Biochem. 1969, 7, 239246.

[2] Chia, C. P., Bomblies, L., Taylor, K. K., Exp. Cell Res. 1998, 244, 340-348.

[3] Bomblies, L., Biegelmann, E., Doring, V., Gerisch, G., Krafft-Czepa, H., Noegel, A. A., Schleicher, M., Humbel, B. M., J. Cell Biol. 1990, 110, 669-679.

[4] Saddler, J. N., Parton, R., Wardlaw, A. C., Experientia 1979, 35, 494-495.

[5] Hitchcock, P. J., Brown, T. M., J. Bacteriol. 1983, $154,269-277$.

[6] Watts, D. J., Ashworth, J. A., Biochem. J. 1970, 119, 171-174.

[7] Harlow, E., Lane, D., Antibodies: A Laboratory Manual, Cold Spring Harbor Laboratory, New York 1988, pp. 511-552.

[8] Laemmli, U. K., Nature 1970, 227, 680-685.

[9] Tsai, C. M., Frasch, C. E., Anal. Biochem. 1982, 119, 115-119.

[10] Towbin, H., Staehelin, T., Gordon, J., Proc. Natl. Acad. Sci. USA 1979, 76, 4350-4354.

[11] Poole, K., Braun, V., J. Bacteriol. 1988, 170, 5146-5152.

[12] Schumann, R. R., Leong, S. R., Flaggs, G. W., Gray, P. W., Wright, S. D., Mathison, J. C., Tobias, P. S., Ulevitch, R. J., Science 1990, 249, 14291431.

[13] Wright, S. D., Ramos, R. A., Tobias, P. S., Ulevitch, R. J., Mathison, J. C., Science 1990, 249, 1431-1433.

[14] Fenton, M. J., Golenbock, D. T., J. Leuk. Biol. $1998,64,25-32$.

[15] Kaca, W., Roth, R. I., Levin, J., J. Biol. Chem. 1994, 269, 25078-25084.

[16] Daffre, S., Faye, I., FEBS Lett. 1997, 408, 127130.

[17] Barbas, J. A., Vazquez, D., Rodriguez-Tebar, A., FEBS Lett. 1985, 193, 289-293.

[18] Lei, M. G., Morrison, D. C., J. Biol. Chem. 1993, 268, 1488-1493.

[19] Gulig, P. A., Hansen, E. J., Infect. Immun. 1985, $49,819-827$.

[20] Hoover, G. J., el-Mowafi, A., Simko, E., Kocal, T. E., Ferguson, H. W., Hayes, M. A., Comp. Biochem. Physiol. B Biochem. Mol. Biol. 1998, 120, 559-569.

[21] Hitchcock, P. J., Infect. Immun. 1984, 46, 202212. 